\title{
The Correlation between the Activities of Digestive Enzymes in the Pancreas and Blood Serum in Chicken
}

\author{
V. G. Vertiprakhov*, A. A. Grozina, V. I. Fisinin, I. A. Egorov \\ All-Russian Research and Technological Institute of Poultry, Sergiev Posad, Russia \\ Email: *vertiprakhov63@mail.ru
}

How to cite this paper: Vertiprakhov, V.G., Grozina, A.A., Fisinin, V.I. and Egorov, I.A. (2018) The Correlation between the Activities of Digestive Enzymes in the Pancreas and Blood Serum in Chicken. Open Journal of Animal Sciences, 8, 215-222. https://doi.org/10.4236/ojas.2018.83016

Received: April 29, 2018

Accepted: June 23, 2018

Published: June 26, 2018

Copyright $\odot 2018$ by authors and Scientific Research Publishing Inc. This work is licensed under the Creative Commons Attribution International License (CC BY 4.0).

http://creativecommons.org/licenses/by/4.0/

(c) (i) Open Access

\begin{abstract}
It is presently an established fact that pancreatic enzymes (amylase, lipase, and trypsin) can enter the bloodstream as well as the intestine. These enzymes normally circulate within the bloodstream in definite concentration ranges. There is a lack of available information on the interrelationships between the enzymatic activities in pancreatic juice and blood serum in poultry. The study presented was aimed at the determination of possible correlation between the activities of the digestive enzymes in pancreatic juice or pancreatic tissue and in blood serum in chicken. The study was performed on Leghorn cockerels with chronically fistulated main pancreatic duct, and broiler chicks at different ages (14, 24, 28, and 35 days). Activities of all digestive enzymes in pancreatic juice in cockerels were found to grow in $1 \mathrm{hr}$ after the feeding: amylase by 1.8 times, lipase 1.5 times, and proteases 1.3 times compared to basal level (after starving). Activity of trypsin in serum significantly increased by $67.4 \%$ in $1 \mathrm{hr}$ after the feeding $(P<0.001)$ while activities of amylase and lipase remained at their respective preprandial levels. The activities of pancreatic enzymes in the pancreas and blood serum in broilers at different ages were positively correlated: $r=0.54$ for amylase, $r=0.96$ for lipase, and $r=0.99$ for trypsin. The strong positive correlation between tryptic activities in the pancreas or pancreatic juice and in blood serum in chicken can be a starting point for further research on the functions of circulatory trypsin which can include the regulation of exocrine pancreatic activity and other vital functions.
\end{abstract}

\section{Keywords}

Blood Serum, Chicken, Pancreas, Pancreatic Enzymes, Pancreatic Juice

\section{Introduction}

It is presently an established fact that the components of the secretion of pan- 
creatic acinar cells including main pancreatic enzymes (amylase, lipase, and trypsin) can enter the bloodstream as well as the intestine [1] [2] [3]. These enzymes normally circulate within the bloodstream in definite concentration ranges though physiological functions of the circulatory enzymes especially pancreatic proteases still remain unclear. There was a hypothesis by Laporte and Tremolieres [4] that circulatory proteases can regulate exocrine secretion of the pancreas: the increase in circulatory trypsin leads to the decrease in pancreatic secretion of digestive enzymes while intravenous injection of trypsin inhibitor leads to the increase in pancreatic secretion. Natural stimuli of the digestion (i.e. gastric digesta entering the small intestine) activate the synthesis of cholecystokinine in the duodenum; this hormone inactivates circulatory trypsin and eliminates inhibiting effect of the latter on pancreatic enzyme secretion hence restoring exocrine activity of the pancreas [5]. The recirculation of proteolytic enzymes was also hypothesized by the analogy of biliary acids [6] [7]. Trypsinogen entering the duodenum within the pancreatic juice after activation by duodenal enterokinase hydrolyses proteins and peptides to amino acids in the small intestine with subsequent absorption of the amino acids into the bloodstream; after that a part of the proteases enters the bloodstream where become inactivated by circulatory protease inhibitor(s) with possible return to the pancreas.

The correlations between the activities of pancreatic enzymes in the pancreas and blood serum were studied in pet animals (e.g. dogs) as related to the acute and/or chronic pancreatitis; exocrine pancreatic insufficiencies in poultry are considered less significant and hence these interrelationships in avian species are still understudied [8]. There is a lack of available information on the interrelationships between the tryptic activities in pancreatic juice and blood serum in poultry [3]. The study presented was aimed at the determination of possible correlations between the activities of the digestive enzymes (including proteases) in pancreatic juice or pancreatic tissue and in blood serum in Leghorn cockerels and broiler chicks.

\section{Material and Methods}

\subsection{Study on Leghorn Cockerels}

The study was performed on 15 Leghorn cockerels raised in the Institute's vivarium until 2 months of age. Five cockerels were then operated to install chronic fistulae into the main pancreatic duct according to the method developed by Batoev and Batoeva [9] and detailed in our previous work [10] to study the enzymatic activities in pancreatic juice. First samples of the juice (portion secreted during $30 \mathrm{~min}$ ) were taken at $9 \mathrm{am}$ after $16 \mathrm{hrs}$ of starving; then the birds were fed $30 \mathrm{~g}$ of standard corn-wheat diet (ME $270 \mathrm{Kcal} / 100 \mathrm{~g}$, crude protein $16 \%$, crude fat $3.6 \%$, crude fiber $5.0 \%$ ) with subsequent sampling of juice during 2.5 hrs with the same sampling periods of $30 \mathrm{~min}$.

Blood samples ( $2-3 \mathrm{ml}, \mathrm{n}=18$ ) were concurrently taken from the axillary vein of the intact starved cockerels. Then the birds were fed $30 \mathrm{~g}$ of the same feed 
and after $1 \mathrm{hr}$ the procedure of blood sampling was repeated. After the addition of aqueous sodium citrate $(3.2 \%, 0.2 \mathrm{ml})$ the samples were centrifuged at 5000 rpm for 5 min to obtain the serum.

\subsection{Study on Broilers}

The age dynamics of exocrine pancreatic function was studied on broilers chicks (cross Smena-8) in conditions of the Institute's vivarium. The birds were fed 3 different corn-wheat diets for starter, grower, and finisher age periods (Table 1).

At all studied ages $(14,21,28$, and 35 days) 20 birds were euthanized, blood samples were taken and blood serum was obtained using the method described above. Then the abdominal wall was dissected, the duodenum found, and the pancreas was withdrawn. The pancreas was weighed, homogenized with cold isotonic Ringer's solution (1200 rpm, $3 \mathrm{~min}$ ) and left for biochemical analyses.

Table 1. Diets for broilers according to age periods.

\begin{tabular}{|c|c|c|c|}
\hline \multirow{2}{*}{ Ingredients, \% } & \multicolumn{3}{|c|}{ Age periods (days): } \\
\hline & $1-14$ & $15-21$ & $22-35$ \\
\hline Wheat & 35.8 & 32.6 & 32.0 \\
\hline Corn & 20.0 & 25.0 & 25.0 \\
\hline Soybean meal & 28.7 & 25.0 & 25.0 \\
\hline Sunflower cake & - & 6.0 & 7.2 \\
\hline Fishmeal & 3.0 & 2.0 & - \\
\hline Sunflower oil & 5.0 & 6.0 & 7.0 \\
\hline Lysine & 0.20 & 0.27 & 0.27 \\
\hline Methionine & 0.34 & 0.25 & 0.24 \\
\hline Salt $(\mathrm{NaCl})$ & 0.26 & 0.30 & 0.35 \\
\hline Monocalcium phosphate & 1.1 & 0.9 & 1.2 \\
\hline Limestone meal & 1.5 & 1.5 & 1.5 \\
\hline Corn gluten meal & 4.0 & - & - \\
\hline Choline chloride & 0.06 & 0.06 & 0.06 \\
\hline \multirow[t]{2}{*}{ Premix $^{*}$} & 0.2 & 0.2 & 0.2 \\
\hline & \multicolumn{2}{|c|}{ Nutritive value (g per $100 \mathrm{~g}$ ): } & \\
\hline ME, Kcal & 304 & 314 & 319 \\
\hline Crude protein & 22.0 & 20.61 & 19.81 \\
\hline Crude fat & 7.08 & 9.11 & 10.16 \\
\hline Crude fiber & 3.69 & 4.22 & 4.42 \\
\hline $\mathrm{Ca}$ & 1.0 & 0.93 & 0.89 \\
\hline Av. P & 0.73 & 0.65 & 0.66 \\
\hline
\end{tabular}

${ }^{*}$ Microelements (ppm): Mn 100; Zn 70; Fe 25; Cu 2.5; Co 1.0; I 0.7; Se 0.2; vitamins (ppm): A 10,000,000 IU; D3 2,500,000 IU; E 20; K 1.0; B1 1.0; B2 5.0; B3 10.0; B4 500; PP 20; B6 3; Bc 0.5; H 0.05. 
All procedures and handling of poultry conformed to local legislation on the welfare of experimental animals.

\subsection{Biochemical Analyses}

The activities of pancreatic enzymes in pancreatic juice, blood serum, and pancreatic homogenate (in broilers) were determined using the kinetic methods. Activity of amylase in pancreatic juice and pancreatic homogenate was determined using Smith-Roy method modified by Ugolev [11] and expressed as mg of hydrolyzed starch per $1 \mathrm{ml}$ of juice (or $1 \mathrm{~g}$ of homogenate) per min; activity of lipase on semi-automatic biochemical analyzer BS3000P (China) using reagent kit by DIAKON-VET Co. (Russia) and expressed as units per $1 \mathrm{ml}$ of juice (or 1 $\mathrm{g}$ of homogenate). The activities of amylase and lipase in blood serum were determined on automatic biochemical analyzer Chem Well 2900 (T) (USA) using reagent kits Liquicolor (Pancreas-Amylase and Lipase, Human, Germany) and filters $405 \mathrm{~nm}$ for amylase and $580 \mathrm{~nm}$ for lipase; the results were expressed as units per liter [12].

Activity of proteases in pancreatic juice and pancreatic homogenate was determined by casein degradation with colorimetric control [13] and expressed as $\mathrm{mg}$ of hydrolyzed casein per $1 \mathrm{ml}$ of juice (or $1 \mathrm{~g}$ of homogenate) per min. Proteases in pancreatic homogenate were preliminary activated by incubation for 14 hrs with extract of the duodenum (containing enterokinase) at $1^{\circ} \mathrm{C}-4^{\circ} \mathrm{C}$ while proteases in pancreatic juice do not require activation due to the original technique of fistulation. The activity of trypsin in blood serum were determined on semi-automatic biochemical analyzer BS3000P (China) using BAPNA ( $\mathrm{N}$ - $\alpha$-Benzoyl-D,L-arginine 4-nitroanilide hydrochloride) as a substrate and expressed as units per liter.

In all cases units of the enzymatic activities are mg of the respective substrate hydrolyzed during $1 \mathrm{~min}$.

The statistical analysis of the data obtained was performed using Microsoft Excel software; significances of the differences were determined using Tukey's range test at $P<0.05$. The average figures are presented as average \pm standard deviation.

\section{Results and Discussion}

The activities of enzymes in pancreatic juice and blood serum can be influenced by different factors. Ingestion of feed and its movement down the gastro-intestinal tract is a powerful stimulator of exocrine pancreatic secretion; during the first minutes after the feeding amounts of juice and enzymes within the juice rise substantially compared to the corresponding preprandial levels (in starved birds) due to the complex-reflex phase of regulation [10].

The data of our experiment on cockerels evidence that the enzymes differ in their postprandial release patterns (Figure 1). Activities of amylase and lipase in pancreatic juice of fistulated cockerels reach maximum in $60 \mathrm{~min}$ after the feeding 


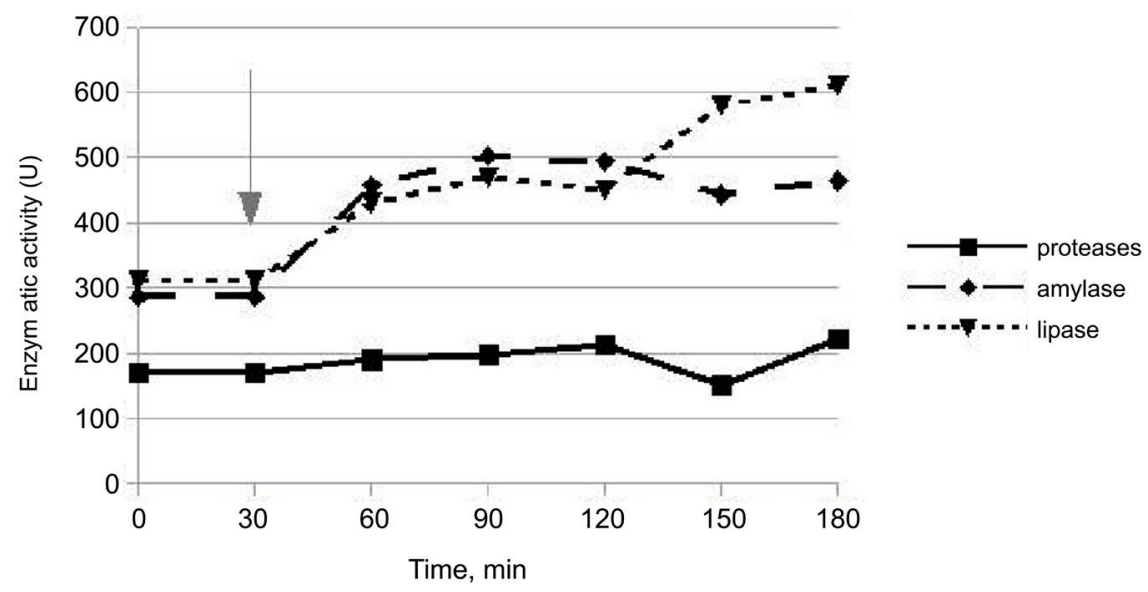

Figure 1. Postprandial dynamics of enzymatic activities in pancreatic juice of fistulated cockerels ( $\downarrow=$ feeding).

while activity of protease in $90 \mathrm{~min}$. The increase in amylase activity was 1.8 times; lipase 1.5 times, and proteases 1.3 times compared to preprandial levels. After reaching their maximums the activities of all the enzymes slightly decreased (lipase first, then amylase and proteases) with subsequent rise corresponding to the neuro-humorous phase of regulation of pancreatic secretion related to the entry of the digesta into the duodenum.

The data on the postprandial changes in the activities of pancreatic enzymes in blood serum are presented in Table 2 . At $1 \mathrm{hr}$ after the feeding average activity of trypsin in serum significantly increased by $67.4 \%(P<0.001)$ while activities of amylase and lipase remained close to their preprandial levels. Our data suggest that tryptic activities in pancreatic juice and blood serum grow in parallel after the feeding (Figure 1, Table 2); this finding is in disagreement with the data reported by Laporte and Tremolieres [4] who found the inverse correlation for serum in rats, probably due to the differences in the methods used for the quantification of tryptic activity.

It should be noted that live bodyweight positively correlated with tryptic activity in serum in both starved and fed cockerels (Pearson's correlation coefficients $r=0.44$ and 0.40 , respectively), unlike the activities of amylase $(r=0.10$ and 0.25$)$ and lipase $(r=0.26$ and 0.13$)$; this relationship can be useful for the assessment of pancreatic health and body growth rate.

Strong and positive correlation between tryptic activities in the pancreas and blood serum was found in our experiment on broilers (Table 3).

The activity of amylase in pancreatic homogenate tended to decrease to 21 days of age with subsequent increase to 35 days; the activity of pancreatic amylase in blood serum decreases with age (4.3 times from 14 to 35 days). Correlation coefficient for amylolytic activities in the pancreas and serum $(r=0.54)$ suggest positive and persistent relationships between these parameters. Amylase activities in the pancreas and serum related to live bodyweight decreased with age, especially between 14 and 21 days of age. 
Table 2. Postprandial changes in enzymatic activities in blood serum in cockerels (U/l) [n $=18]$.

\begin{tabular}{|c|c|c|c|c|c|c|c|}
\hline \multirow{2}{*}{ No } & \multirow{2}{*}{$\begin{array}{c}\text { Live } \\
\text { bodyweight, } \mathrm{g}\end{array}$} & \multicolumn{2}{|c|}{ Trypsin } & \multicolumn{2}{|c|}{ Amylase } & \multicolumn{2}{|c|}{ Lipase } \\
\hline & & starved & fed & starved & fed & starved & fed \\
\hline 1 & 1759 & 70.0 & 104.6 & 236.7 & 254.8 & 14.8 & 14.7 \\
\hline 2 & 1670 & 53.4 & 124 & 583 & 361.4 & 18.5 & 7.2 \\
\hline 3 & 1678 & 56.3 & 141.5 & 358.3 & 216.1 & 24.6 & 12.8 \\
\hline 4 & 1486 & 30.8 & 55.2 & 140.7 & 180.0 & 14.0 & 5.8 \\
\hline 5 & 1365 & 38.4 & 68.8 & 286.0 & 196.5 & 14.8 & 8.7 \\
\hline 6 & 1606 & 41.9 & 75.1 & 205.1 & 99.7 & 11.7 & 6.9 \\
\hline 7 & 1614 & 42.7 & 90.8 & 423.2 & 397.0 & 19.6 & 12.4 \\
\hline 8 & 1704 & 38.7 & 71.8 & 251.3 & 195.5 & 14.5 & 11.3 \\
\hline 9 & 1758 & 77.3 & 86.6 & 168.4 & 205.1 & 23.7 & 14.2 \\
\hline 10 & 1669 & 51.1 & 78.6 & 198.5 & 32.2 & 23.4 & 10.3 \\
\hline 11 & 1631 & 50.1 & 89.7 & 285.1 & 213.8 & 18.0 & 10.4 \\
\hline 12 & 1740 & 70.6 & 126.1 & 228.7 & 607.1 & 15.5 & 21.6 \\
\hline 13 & 1651 & 57.7 & 73.9 & 230.7 & 216.6 & 23.4 & 25.5 \\
\hline 14 & 1645 & 62.1 & 117.2 & 177.4 & 167.9 & 24.1 & 23.7 \\
\hline 15 & 1673 & 69.3 & 103.9 & 392.0 & 366.4 & 18.9 & 20.0 \\
\hline 16 & 1690 & 59.2 & 91.5 & 485.0 & 229.7 & 28.4 & 20.7 \\
\hline 17 & 1706 & 48.6 & 72.8 & 198.5 & 234.7 & 41.0 & 21.1 \\
\hline 18 & 1519 & 83.7 & 103.8 & 205.1 & 228.2 & 25.1 & 36.2 \\
\hline Avg. & $\begin{array}{l}1642.4 \\
\pm 23.5\end{array}$ & $\begin{array}{c}55.6 \pm \\
3.52\end{array}$ & $\begin{array}{c}93.1 \pm \\
5.48^{* * *}\end{array}$ & $\begin{array}{c}280.8 \pm \\
28.40\end{array}$ & $\begin{array}{c}244.6 \pm \\
29.61\end{array}$ & $\begin{array}{c}20.8 \pm \\
1.62\end{array}$ & $\begin{array}{c}15.4 \pm \\
1.97\end{array}$ \\
\hline
\end{tabular}

Table 3. Age dynamics of the activities of pancreatic enzymes (absolute and per $1 \mathrm{~g}$ of live bodyweight) in pancreatic homogenate and blood serum in broilers [ $\mathrm{n}=20]$.

\begin{tabular}{|c|c|c|c|c|c|c|c|}
\hline \multirow[b]{2}{*}{ Age, $d$} & \multirow{2}{*}{$\begin{array}{c}\text { Live } \\
\text { bodyweight } \\
\text { (BW), g }\end{array}$} & \multicolumn{2}{|c|}{ Amylase in: } & \multicolumn{2}{|c|}{ Lipase in: } & \multicolumn{2}{|c|}{ Trypsin in: } \\
\hline & & $\begin{array}{l}\text { pancreas, } \\
\mathrm{mg} / \mathrm{g} / \mathrm{min}\end{array}$ & $\begin{array}{l}\text { serum, } \\
\mathrm{U} / \mathrm{L}^{\star}\end{array}$ & $\begin{array}{c}\text { pancreas, } \\
\mathrm{U} / \mathrm{g}\end{array}$ & $\begin{array}{c}\text { serum, } \\
\mathrm{U} / \mathrm{L}\end{array}$ & $\begin{array}{l}\text { pancreas, } \\
\mathrm{mg} / \mathrm{g} / \mathrm{min}\end{array}$ & $\begin{array}{l}\text { serum, } \\
\mathrm{U} / \mathrm{L}\end{array}$ \\
\hline 14 & $429 \pm 7.6$ & $18440 \pm 443.8$ & $1296 \pm 58.3$ & $100 \pm 4.62$ & $16 \pm 1.7$ & $317 \pm 48.9$ & $11 \pm 0.5$ \\
\hline \multicolumn{2}{|c|}{ per $1 \mathrm{~g}$ of BW } & 42.9 & 3.02 & 0.2 & 0.04 & 0.74 & 0.02 \\
\hline 21 & $839 \pm 19.5$ & $13800 \pm 1057.2$ & $525 \pm 51.4$ & $108 \pm 6.2$ & $18 \pm 2.2$ & $278 \pm 30.1$ & $10 \pm 3.6$ \\
\hline \multicolumn{2}{|c|}{ per $1 \mathrm{~g}$ of $\mathrm{BW}$} & 16.4 & 0.62 & 0.1 & 0.02 & 0.33 & 0.01 \\
\hline 28 & $1326 \pm 38.4$ & $15160 \pm 1254.7$ & $516 \pm 86.7$ & $83 \pm 7.9$ & $10 \pm 1.4$ & $325 \pm 46.9$ & $13 \pm 1.6$ \\
\hline \multicolumn{2}{|c|}{ per $1 \mathrm{~g}$ of $\mathrm{BW}$} & 11.4 & 0.39 & 0.06 & 0.01 & 0.24 & 0.01 \\
\hline 35 & $2115 \pm 98.3$ & $17343 \pm 617.5$ & $298 \pm 28.5$ & $106 \pm 4.1$ & $20 \pm 2.8$ & $487 \pm 43.2$ & $23 \pm 3.6$ \\
\hline \multicolumn{2}{|c|}{ per $1 \mathrm{~g}$ of $\mathrm{BW}$} & 8.2 & 0.14 & 0.05 & 0.01 & 0.23 & 0.01 \\
\hline \multicolumn{3}{|c|}{ Correlation coefficient pancreas $\mathrm{x}$ serum } & 0.54 & & 0.96 & & 0.99 \\
\hline
\end{tabular}

*units $(\mathrm{U})$ of the enzymatic activities are $\mathrm{mg}$ of the respective substrate hydrolyzed during $1 \mathrm{~min}$. 
The activity of lipase in pancreatic homogenate followed a wavy pattern with maximum at 21 and minimum at 28 days of age (probably resulted from the diet change at 15 days of age) while activity in blood serum tended to increase with age. These parameters were strongly and positively correlated $(r=0.96)$. Lipase activities related to live bodyweight decreased with age though with lesser rate in compare to amylase.

The activity of trypsin in pancreatic homogenate decreased from 14 to 21 days of age with subsequent rise to 35 days; this parameter increased from 14 to 35 days of age by $53.6 \%$. The tryptic activity in serum followed a similar pattern; the increase of this parameter from 14 to 35 days of age was more than 2 times. Tryptic activities in the pancreas related to live bodyweight decreased with age, especially until 21 days of age, while tryptic activity in serum declined between 14 and 21 days of age and later remained relatively constant.

Robust and direct correlation $(\mathrm{r}=0.99)$ was found between tryptic activities in the pancreas and serum, and this interrelationship is not accidental. It is well known that blood contains trypsin inhibitor(s) inactivating the enzyme entering the bloodstream. The absence of any sound correlation between tryptic and antitryptic activities in serum reported earlier [14] is in agreement with early opinion that physiological role of circulatory antitrypsin ( $\alpha 1$-proteinase inhibitor, A1PI) is rather related to leucocytic proteases than trypsin [15].

\section{Conclusion}

Our experimental data suggest the strong positive correlation between tryptic activities in the pancreas or pancreatic juice and in blood serum in chicken. This fact can be a starting point for further research on the functions of circulatory trypsin which can include the regulation of exocrine pancreatic activity and other vital functions related to the regulation of arterial blood pressure, inflammatory immune responses, blood clotting, etc.

\section{Acknowledgements}

The study was financed by Russian Science Foundation, grant No 16-16-04089.

\section{References}

[1] Ugolev, A.M., Iezuitova, N.N., Masevich, C.G., Nadirova, T.Y. and Timofeyeva, N.M. (1969) The Study on the Digestive System in Human. "Nauka" Publication, Leningrad. (In Russian)

[2] Korot'ko, G.F. (2013) Formation of Enzyme Component of Digestive Glands (Review). Physical Training \& Sports-Science \& Practice, No 1, 51-57. (In Russian)

[3] Vertiprakhov, V.G., Grozina, A.A. and Dolgorukova, A.M. (2016) The Activity of Pancreatic Enzymes on Different Stages of Metabolism in Broiler Chicks. Agricultural Biology (Sel'skokhozyaistvennaya Biologiya, Moscow), 51, 509-515. https://doi.org/10.15389/agrobiology.2016.4.509eng

[4] Laporte, J.C. and Tremolieres, J. (1971) Regulation hormonale de la sécrétion enzymatique du pancréas exocrine. Comptes rendus de l'Académie des Sciences ser. 
D, 273, 1205-1207.

[5] Layer, P., Jansen, J.B.M.J., Cherian, L., Lamers, S.B.H.W. and Goebell, H. (1990) Feedback Regulation of Human Pancreatic Secretion: Effects of Protease Inhibition on Duodenal Delivery and Small Intestinal Transit of Pancreatic Enzymes. Gastroenterology, 98, 1311-1319. https://doi.org/10.1016/0016-5085(90)90350-A

[6] Rothman, S., Leibow, C. and Isenman, L. (2002) Conservation of Digestive Enzymes. Physiological Reviews, 82, 1-18. https://doi.org/10.1152/physrev.00022.2001

[7] Korot'ko, G.F. (2003) Recretion of Enzymes and Hormones by Exocrine Glands. Uspekhi Fisiologicheskikh Nauk, 34, 21-32. (In Russian)

[8] Amann, O., Visschers, M.J.M., Dorrestein, G.M., Westerhof, I. and Lumeij, J.T. (2006) Exocrine Pancreatic Insufficiency in Pigeons. Avian Pathology, 35, 58-62. https://doi.org/10.1080/03079450500465791

[9] Batoev, T.Z. and Batoeva, S.T. (1970) The Method of Fistulation of Birds for Investigations on Pancreatic Function and Bile Secretion. Physiological Journal of USSR, 56, 1867-1868. (In Russian)

[10] Vertiprakhov, V.G. and Egorov, I.A. (2016) The Influence of Feed Intake and Conditioned Reflex on Exocrine Pancreatic Function in Broiler Chicks. Open Journal of Animal Science, 6, 298-303. https://doi.org/10.4236/ojas.2016.64034

[11] Merina-Gluzkina, V.M. (1965) The Comparative Evaluation of Saccharizing vs. Dextrinizing Methods of Determination of Amylase Activity in Intact Humans and Patients with Acute Pancreatitis. Russian Clinical Laboratory Diagnostics, 10, 143. (In Russian)

[12] Mikhailova, A.G., Khairullin, R.F., Rumsh, L.D., Demidyuk, I.V., Kostrov, S.V., Grinberg, N.V., Burova, T.V. and Grinberg, V.Y. (2014) Cloning, Sequencing, Expression, and Characterization of Thermostability of Oligopeptidase B from Serratia proteamaculans, a Novel Psychrophilic Protease. Protein Expression and Purification, 93, 63-76. https://doi.org/10.1016/j.pep.2013.10.011

[13] Batoev, T.Z. (1971) Photometric Analysis of Proteolytic Enzymatic Activities in Pancreas and Its Juice Using the Decrease in Casein Concentration as a Criterion. The Proceedings of Buryat Agriculture Institute, 25, 122-126. (In Russian)

[14] Vertiprakhov, V.G., Grozina, A.A., Egorov, I.A., Lenkova, T.N., Manukyan, V.A. and Egorova, T.A. (2017) On the Activities of Pancreatic Proteases and alpha-1 Proteinase Inhibitor in Meat-Type Chicken. Open Journal of Animal Science, 7, 289-296. https://doi.org/10.4236/ojas.2017.73022

[15] Prado, J.L. (1970) Proteolytic Enzymes as Kininogenases. In: Erdös, E.G. and Wilde, A.F., Eds., Bradykinin, Kallidin and Kallicrein, Springer-Verlag, New York, 162-163. https://doi.org/10.1007/978-3-642-46222-1_8 